\title{
Organizational Citizenship Behavior Ability to Increase the Effect of Organizational Climate, Work Motivation and Organizational Justice on Employee Performance
}

\author{
Yupono B \\ STIE Malangkucecwara Malang \\ Siwi Dyah Ratnasari \\ STIE Malangkucecwara Malang
}

\begin{abstract}
This research aim is to examine the effect of Organization Climate, Work Motivation and Organizational Justice on Employee Performance mediated by Organizational Citizenship Behavior (OCB). The population are 50 samples. The data is collected by questionnaires and analyzed by path analysis. The test results prove that Organizational Climate, Work Motivation and Organizational Justice significantly affect on Employee Performance with OCB as mediation variable.Company should increase Organizations justice through comparable wages with the work and on time. Company should consistent to implement company regulations, with polite and equal treatment. Improve Organizational Citizenship Behavior (OCB) by helping each other without expecting rewards, replacing the absence co-workers, willing to work overtime without being given a salary and have sharing among employees in handling problems. Good organizational climate, high work motivation and Organizational Justice and supported by OCB
\end{abstract}

Keywords: Organizational Climate, Work Motivation, Organizational Justice, OCB, Performance

DOI: $10.7176 /$ JRDM/59-04

Publication date:September $30^{\text {th }} 2019$

\section{INTRODUCTION}

Organizational Citizenship Behavior is extra-role behavior or also called OCB (Harper, 2015). Employees should work without coercive and voluntary in organization to realize the organization's vision and mission. Waspodo and Minadaniati (2012) said that employees have a willingness to do more than their formal responsibilities; this willingness is then known as OCB. Ahmad and Tanzin (2016) suggest OCB is a form of voluntary activity from organizations members to support organizational functions. OCB arises from basic policies of company to do voluntarily and there is no coercion (Andriani, 2012). OCB can also be defined as informal help and directly do not relate to individual competence in payroll system (Ariani, 2012).

Newstrom \& Davis (1996) defined Organizational Climate as a human environment relates to employees in organizations where they work; organizational climate can foster employee morale and increase OCB. The organizational climate will determine how the company carries out its duties and responsibilities consistent with procedure (Purwanti and Nurhayati, 2016). The organizational change has a strong effect on teamwork. Organization attention employees work problems through constructive relationships with work requirements can provide a positive environment for employees to rise OCB behavior (Prihatsanti and Dewi, 2010). Meylandani (2013) showed a strong relationship between organizational climate and OCB.

Motivation is a process as an initial step to act to achieve certain goals. Work motivation can become a driving force for humans to do their duties and responsibilities (Ek and Elegwa, 2013). Zabielske et al (2015) said that employees whose the needs are not met can become motivation to meet their needs. OCB is also needed by work motivation. Abuiyada and Shih (2012) said that motivation can be interpreted as a force from inside or outside and spirit to achieve the desire.

Nandan and Abdul (2015) said that Organizational justice is the concept of perceptions about their organization, and how these perceptions affect employee loyalty to organization. Unfair or injustice treatment not only reduces work performance but also reduces the quality of work and cooperation between workers (Awang and Wan, 2015 and Tahseen and Muhammad, 2016). Oge et al. (2014) said that the fair concept contains several things; companies should be concern as work division, wage, award, treatment, and other things that determine the quality of interactions within company. Fatimah et al (2011) stated that organizational justice is the result of approved individual subjective perceptions by others around him. Fair and consistent superiors to each subordinate will create a positive perception to justice and will increase their satisfaction and commitment (Rohyani, 2014). A fair development process is important to consider (Ratnawati and Khairul, 2013). The Sanhaji et al (2016) showed a positive relationship between organizational justice and OCB. In addition, OCB positively affect distributive, procedural and interaction justice.

Problems related to organizational climate in CV. Ursa Mayora Consultant is a poor relationship to causes 
problems and differences of opinion between superiors and subordinates and subordinates with subordinates to affect on uncomfortable working atmosphere. It relates related to organizational climate problems.

The work placement does not fit with employees educational background. In addition to the poor working conditions, rooms arrangement is not neat; it causes a lack of freedom when employees do their activities. The organizational justice problem is not comparable to employee wage. The company often late to give the wage to employees. The problems cause employees difficult to show Organizational Citizenship Behavior (OCB). It causes a low effectiveness and work productivity. Therefore, researchers are interested to examine the Organizational Citizenship Behavior (OCB) ability to increase the effect of Organizational Climate, Work Motivation and Organizational Justice on Employee Performance.

\section{Problem Formulation}

1. Does Organizational Climate have a significant effect on Organizational Citizenship Behavior (OCB)?

2. Does Work Motivation have a significant effect on Organizational Citizenship Behavior (OCB)?

3. Does Organizational Justice have a significant effect on Organizational Citizenship Behavior (OCB)?

4. Does Organizational Citizenship Behavior (OCB) have a significant effect on Performance?

5. Does Organizational Climate have a significant effect on Performance?

6. Does Work Motivation have a significant effect on Performance?

7. Does Organizational Justice have a significant effect on Performance?

8. Does Organizational Citizenship Behavior (OCB) have ability to increase the effect of Organizational Climate on Performance?

9. Does Organizational Citizenship Behavior (OCB) have ability to increase the effect of Work Motivation on Performance?

10. Does Organizational Citizenship Behavior (OCB) have ability to increase the effect of Organizational Justice on Performance?

\section{Research purposes}

1. Finding the effect of Organizational Climate on Organizational Citizenship Behavior (OCB)

2. Finding the effect of Work Motivation on Organizational Citizenship Behavior (OCB)

3. Finding the effect of Organizational Justice on Organizational Citizenship Behavior (OCB)

4. Finding the effect of Organizational Citizenship Behavior (OCB) on Performance

5. Finding the effect of Organizational Climate on Performance

6. Finding the effect of Work Motivation on Performance

7. Finding the effect of Organizational Justice on Performance

8. Finding the effect of Organizational Climate on Performance mediated by Organizational Citizenship Behavior (OCB)

9. Finding the effect of Work Motivation on Performance mediated by Organizational Citizenship Behavior (OCB)

10. Finding the effect of Organizational Justice on Performance mediated by Organizational Citizenship Behavior (OCB)

\section{Framework}

This research examines ability of Organizational Citizenship Behavior (OCB) to increase the effect of Organizational Climate, Work Motivation and Organizational Justice on Employee Performance (Study at CV. Ursa Mayora Consultant). The research framework is shown in figure 1 below. 


\section{Organization Climate}

- Structure

- Standard

- Responsibility

- Award

- Support

- Commitment

(Stringer, 2002)

\section{Motivation}

- Achievment

- Recognition

- Work in Self

- Responsibility

- Advancement.

(Luthans, 2002 )

Organization Justice

- Distributive justice

- Procedural justice

- Interactional justice

(Toenblom, 1992)

\section{Performance}

- Quantity

- Quality

- Reliability

- Altruism

- Conscientiousness

- Courtesy

- Sportsmanship

- Civic Virtue

\section{(Organ, 1988 )}

- Absence

- Cooperation ability

(Mathis and

Jackson, 2006)

Figure 1. Research Framework

\section{Research Hypothesis}

Hypothesis is a temporary answer or an opinion with low truth and not convincing. The answers are only based on relevant theory that needs to be tested or proven (Moh Nazir, 2000). Based on theory and previous research, the hypothesis model can be drawn below.

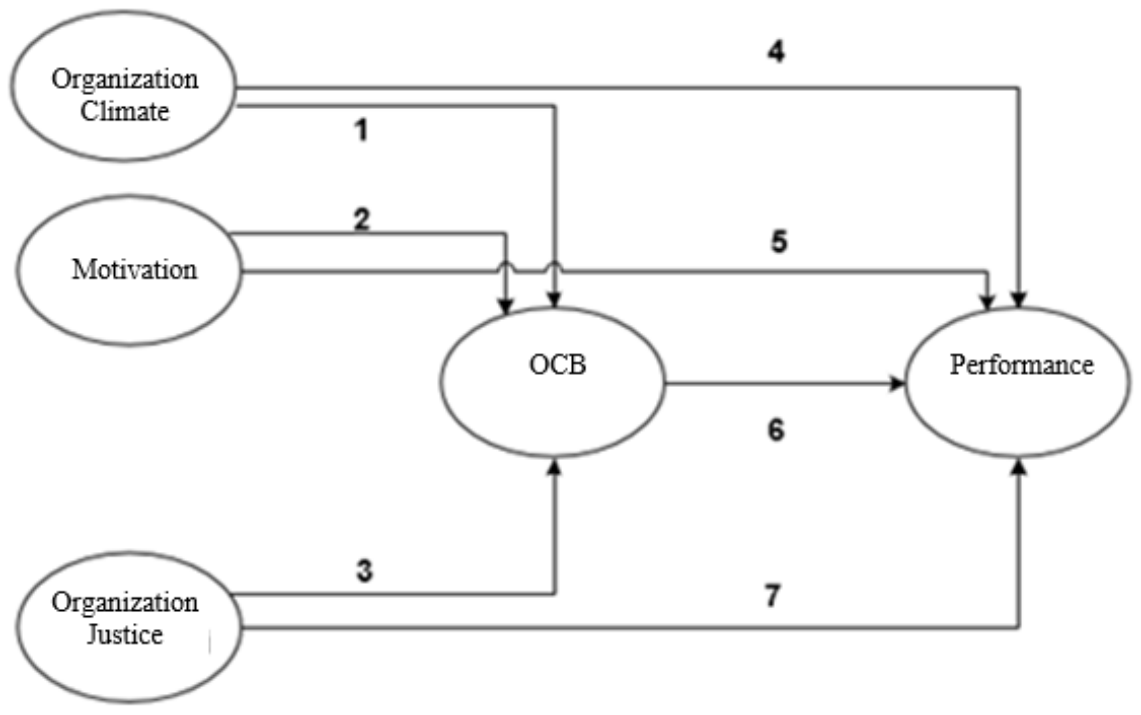

Figure 2. Hypotheses Framework 
Based on figure 2, the hypotheses are stated below.

H1: Organizational Climate has a significant effect on Organizational Citizenship Behavior (OCB).

H2: Work Motivation has a significant effect on Organizational Citizenship Behavior (OCB)

H3: Organizational Justice has a significant effect on Organizational Citizenship Behavior (OCB)

H4: Organizational Citizenship Behavior (OCB) has a significant effect on performance

H5: $\quad$ Organizational Climate has a significant effect on Performance

H6: Work motivation has a significant effect on performance

H7: Organizational Justice has a significant effect on Performance

H8: Organizational Citizenship Behavior (OCB) has ability to increase the effect of Organizational Climate on Performance

H9: Organizational Citizenship Behavior (OCB) has ability to increase the effect of Work Motivation on Performance

H10: Organizational Citizenship Behavior (OCB) has ability to increase the effect of Organizational Justice on Performance

\section{RESEARCH METHODS}

\section{Types of research}

It is a quantitative research type to focuses on testing the hypotheses to find the truth. The statistical tests are used to provide explanatory information to get valid results. This research uses explanatory research to explain relationship between the researched variables.

\section{Research Subjects}

The research subjects are employees at CV. Ursa Mayora Consultant.

\section{Research Object}

The research object is Organizational Citizenship Behavior (OCB) has ability to mediate the Effect of Organizational Climate, Work Motivation and Organizational Justice on Employee Performance (Study at CV. Ursa Mayora Consultant).

\section{Research location}

This research was conducted at CV. Ursa Mayora Consultant located in Perumahan Puri Cempaka Putih II Blok AR. 10 Malang.

\section{Population and Samples}

Sugiyono (2008) said that population is a generalization area consisting of objects or subjects with certain qualities and characteristics. This research population is 102 employees of CV. Ursa Mayora Consultants.

Samples are part of population to represent the studied population. Samples reflect all the characteristics possessed by entire population of Arikunto (1998). The sample is part of population to be studied or a portion of characteristics possessed by population (Sugiyono, 2002). The samples were taken using Slovin formula with following calculations:

$$
\begin{aligned}
& \mathrm{n}=\mathrm{N} / \mathrm{N}(\mathrm{d}) 2+1 \\
& \mathrm{n}=102 / 102(0.10) 2+1 \\
& \mathrm{n}=50.4
\end{aligned}
$$

Description:

$$
\begin{array}{ll}
\mathrm{N}= & \text { Population } \\
\mathrm{n}= & \text { Samples } \\
\mathrm{d}= & \text { Allowance }
\end{array}
$$

Above calculations shows that samples with an allowance of $10 \%$ are 50.4 or rounded up to 50 . They consist of Directors, Deputy Directors, Managers, Secretaries, Experts, Division, Sub-Division, Sections and Staff.

\section{Data Sources and Types}

This research uses primary data from field research and collected by observations and questionnaires. Observation is a technique to collect data based on observations to use the eyes or ears directly without standardized tools. This data collection is intended to know thoroughly the actual situation of studied object. The observation is focused on predetermined indicator of Organizational Citizenship Behavior (OCB), Organizational Climate, Work Motivation, Organizational Justice and Performance variables.

Questionnaires are a set of questions or statements that must be answered or completed by respondent. Each indicator is represented by several questionnaire items to get valid and reliable questionnaires to represent each 
variable.

\section{Research Instruments Testing}

The data consist of primary data or raw data that will be processed to create valid data. Steps or data processing procedures carried out in this research are below validity and reliability tests.

Validity test is used to examine the accuracy measurement instrument. High validity is shown by the instrument function in measurement and gives the results according based on measurement purpose. Validity testing is done by product moment correlation analysis. The instruments are validity if the probability is $<0.05$. Test results show that indicators of Organizational Climate (X1), Motivation (X2), Organizational Justice (X3), Organizational Citizenship Behavior $(\mathrm{Z})$ and Performance $(\mathrm{Y})$ are valid because $\mathrm{r}$ count $>$ from $r$ table $(0.273)$.

\section{Reliability Test}

Reliability test is done by Spearman Rank for ordinal data. Arikunto (1998) said that the analysis is used to determine the relationship between independent variables $(\mathrm{x})$ with dependent variables (y). The indicators are valid if the cronbach alpha value is above 0.60 . The test results are shown in table 1 below.

Table 1. Reliability test

\begin{tabular}{|l|c|c|}
\hline \multicolumn{1}{|c|}{ Variables } & Cronbach's Alpha & Description \\
\hline Organization Climate (X1) & 0.73 & Reliable \\
\hline Motivation (X2) & 0.50 & Reliable \\
\hline Organization Justice (X3) & 0.72 & Reliable \\
\hline OCB (Z) & 0.74 & Reliable \\
\hline Performance (Y) & 0.74 & Reliable \\
\hline
\end{tabular}

Table 1 shows that Cronbach's Alpha of all variables are greater than 0.6 (Guilford, 1956: 145), it means that all instruments used are reliable.

\section{Data analysis method \\ Descriptive Statistics Analysis}

Descriptive statistical analysis method formulates and interpreting the existing data to provide a clear figure of the company.

\section{Classic assumption test}

The classic assumption tests should be fulfilled before regressing the data. It consists of normality, multicolinierity, Autocorrelation and heteroscedasticity tests.

1. Normality test. The normality test is done to examine whether the data has normal distribution. Test result shows that the data is spread above and below the Normal P-P Plot. It means that data has normal distribution.

2. Multicollinearity Test. Multicollinearity test examines the correlation between independent variables and dependent variables in a regression model. VIF value below 10 shows no correlation. Research results shows that the data has VIF value below 10, it means that the data shows no correlation

3. Autocorrelation Test. Autocorrelation test examines the disturbing effect of each independent variable. The data has no autocorrelation if the has Durbin Watson $0<\mathrm{DW}<4$. Test results show that the Durbin Watson values are between 0 and 4 , therefore the data has no multicollinearity.

4. Heteroscedasticity test. Heteroscedasticity test examine the variance difference from residual data. This research uses graph analysis of plot for the predicted value of dependent variable (ZPRED) and residual (SRESID). The research results show that the data spread above and below zero line, it means the data fulfil the Heteroscedasticity condition.

\section{Hypothesis Testing}

The hypotheses testing are done with Multiple Regression analysis using SPSS 22 for Windows. This test is done to examine the direct effect of independent variables to dependent variables. The indirect effects are calculated by Sobel test.

\section{RESEARCH RESULTS}

Demography analysis

The demographic profile of 50 respondents show that majority age is between 20-29 years (52\%), classified as young. The male respondents were higher than women with a ratio of $64 \%$ compared to $36 \%$. Most of 
respondents received a final education at Bachelor level (S1) of 54\% and longest tenure was between 1-2 years at $28 \%$.

\section{Descriptive Statistics Analysis}

The distribution frequency score of all variables show high average. Organizational Climate (X1) has average score of 4.11, Motivation (X2) has average score of 4.20, Organizational Justice (X3) has average score of 4.11, Organizational Citizenship Behavior (Z) has average score of 4.29 and Performance (Y) has average score of 4.13. It means all researched variables are perceived well by respondents.

The Direct and Indirect Effect of Organizational Climate, Work Motivation, Organizational Justice on Organizational Citizenship Behavior and the Impact on Performance

Heteroscedasticity test show that the points has irregular pattern. It can be concluded that data has heteroscedasticity. This means that regression function in this research does not have disturbance because the variants are not the same.

\section{Partial Test (Statistic t Test)}

Partial test is used to examine the significance of partial coefficient of each regression coefficient at a significant level of 5\%. The hypothesis is accepted if the significance level below 0.05 . The analysis results for the direct and indirect effects is shown at table 2 and explained below.

Table 2. The Results of Direct and Indirect Effect

\begin{tabular}{|l|c|c|c|c|}
\hline \multirow{2}{*}{ Variables } & \multirow{2}{*}{ Significance } & \multicolumn{2}{c|}{ Effect } & \multirow{2}{*}{ Total } \\
\cline { 3 - 4 } & & Direct & Indirect & \\
\hline $\mathrm{X} 1 \rightarrow \mathrm{Z}$ & 0.002 & 0.399 & - & 0.399 \\
\hline $\mathrm{X} 2 \rightarrow \mathrm{Z}$ & 0.047 & 0.240 & - & 0.240 \\
\hline $\mathrm{X} 3 \rightarrow \mathrm{Z}$ & 0.005 & 0.266 & - & 0.266 \\
\hline $\mathrm{Z} \rightarrow \mathrm{Y}$ & 0.004 & 0.333 & - & 0.333 \\
\hline $\mathrm{X} 1 \rightarrow \mathrm{Y}$ & 0.001 & 0.427 & - & 0.427 \\
\hline $\mathrm{X} 2 \rightarrow \mathrm{Y}$ & 0.046 & -0.277 & - & -0.277 \\
\hline $\mathrm{X} 3 \rightarrow \mathrm{Y}$ & 0.043 & 0.259 & - & 0.259 \\
\hline $\mathrm{X} 1 \rightarrow \mathrm{Z} \rightarrow \mathrm{Y}$ & 0.001 & 0.427 & $0.399 \times 0.333=0.132$ & 0.559 \\
\hline $\mathrm{X} 2 \rightarrow \mathrm{Z} \rightarrow \mathrm{Y}$ & 0.046 & -0.277 & $0.240 \times 0.333=0.079$ & -0.198 \\
\hline $\mathrm{X} 3 \rightarrow \mathrm{Z} \rightarrow \mathrm{Y}$ & 0.043 & 0.259 & $0.266 \times 0.333=0.088$ & 0.347 \\
\hline $\mathrm{e}_{1}$ & 0.698 & 0.698 & & - \\
\hline $\mathrm{e}_{2}$ & 0.620 & 0.620 & & 0.698 \\
\hline
\end{tabular}

Source: Data processed in 2018

The description for the effect of independent variables on dependent variables for table 2 can be explained below.

1. The $t$ test result for the effect of Organizational Climate on Organizational Citizenship Behavior has coefficient value of 0.399 and a significance level of $0.002<0.05$. Therefore, hypothesis $\mathrm{H} 1$ that Organizational Climate has a significant effect on Organizational Citizenship Behavior (OCB) is accepted.

2. The $t$ test result for the effect of Motivation on Organizational Citizenship Behavior has coefficient value of 0.240 and significance level is $0.047<0.05$. Therefore, hypothesis $\mathrm{H} 2$ that Work Motivation has a significant effect on Organizational Citizenship Behavior (OCB) is accepted.

3. The $t$ test result for the effect of Organizational Justice on Organizational Citizenship Behavior has coefficient value of 0.266 and significance level is $0.005<0.05$. Therefore, hypothesis $\mathrm{H} 3$ that Organizational Justice has a significant effect on Organizational Citizenship Behavior is acceptable is accepted.

4. The t test result for the effect of Organizational Citizenship Behavior on Performance has coefficient value of 0.333 and significance level of $0.004<0.05$. Therefore, hypothesis H4 that Organizational Citizenship Behavior on Performance has a significant effect on Performance is accepted.

5. The t test result for the effect of Organizational Climate on Performance has coefficient value of 0.427 and significance level of $0.001<0.05$. Therefore, hypothesis H5 that Organizational Climate has a significant effect on Performance is accepted.

6. The $t$ test result for the effect of has coefficient value of -0.227 and significance level of $0.046<0.05$. 
Therefore, hypothesis H6 that motivation has a significant effect on performance is accepted.

7. The $t$ test result for the effect of Organizational Justice on Performance has coefficient value of 0.259 and significance level of $0.043<0.05$. Therefore, hypothesis H7 that Organizational Justice has a significant effect on Performance is accepted.

The mediation effect can be calculated by Sobel test to sum the direct effects plus indirect effects (Baron and Kenny, 1986). The mediation role is accepted if the total effect is greater than the direct effect. Table 2 shows that the effect of Organizational Climate, Motivation, and Organizational Justice on Performance through Organizational Citizenship Behavior as an intervening variable have total effect is greater than the direct effect. Therefore, it can be concluded that Organizational Citizenship Behavior can mediate the Effect of Organizational Climate, Motivation, Organizational Justice on Performance that (H8, H9 and $\mathrm{H} 10$ are accepted).

\section{DISCUSSION}

\section{The Effect of Organizational Climate on OCB}

Testing the effect of organizational climate on OCB shows that organizational climate has a significant effect on OCB. This research result is consistent with previous studies of Ukkas and Latif (2017), Agyemang (2013), Lubis (2015), Waspodo and Minadaniati (2012). This implies that Organizational Citizenship Behavior (OCB) will improve the organizational climate, including employees feeling happy to complete their work, employees are given the opportunity to argue, and employees are very responsible in their duties and jobs.

\section{Effects of Motivation on OCB}

Testing the effect of motivation on OCB shows that motivation had a significant effect on OCB. These results can be seen from a significant value of $0.047<0.05$.

\section{Effect of Organizational Justice on OCB}

Testing results show that organizational justice has an effect on OCB. It shows that organizational justice has a significant effect on OCB. These results can be seen from a significant value of $0.005<0.05$.

\section{Effect of OCB ON Performance}

Testing results show that OCB has an effect on Performance. It shows that OCB has a significant effect on Performance. These results can be seen from a significant value of $0.0,004<0.05$.

\section{Effect of Organizational Climate on Performance}

Testing results shows that OCB has effect on performance. It shows that OCB has a significant effect on performance. These results can be seen from significant value of $0.004<0.05$.

\section{Effect of Motivation on Performance}

Testing results shows that motivation has significant effects on performance. These results can be seen from a significant value of $0.046<0.05$.

\section{Effect of Organizational Justice on Performance}

Testing results shows that organizational justice has an effect on performance, showing that Organizational Justice affects on Performance. These results can be seen from a significant value of $0.043<0.05$.

Effect of Organizational Climate, Organizational Motivation and Justice on Performance with OCB as an Intervening variable

Testing the effect of organizational climate, organizational motivation and fairness on performance with OCB as an intervening variable shows that Organizational Citizenship Behavior (OCB) can become an intervening variable on performance. This can be seen from Organizational Climate, Motivation and Justice Organizations have an effect on Organizational Citizenship Behavior (OCB), Organizational Citizenship Behavior (OCB) affects on Performance and total effect is greater than direct effect so it can be concluded that Organizational Citizenship Behavior can mediate the Effect of Organizational Climate, Motivation, and Organizational Justice on Performance.

\section{CONCLUSION}

Based on above research results and discussion, the conclusion can be stated below.

1. Organizational Climate has a significant effect on Organizational Citizenship Behavior (OCB). The results of research revealed that coefficient value of 0.399 and a significance level of $0.002<0.05$.

2. Work motivation has a significant effect on Organizational Citizenship Behavior (OCB). The results of research revealed that coefficient value of 0.240 and significance level is $0.047<0.05$. 
3. Justice Organizations has a significant effect on Organizational Citizenship Behavior (OCB). The results of research revealed that coefficient value of 0.266 and significance level is $0.005<0.05$.

4. Organizational Citizenship Behavior (OCB) has a significant effect on performance. The results of research revealed that coefficient value of 0.333 and significance level of $0.004<0.05$.

5. Organization Climate has a significant effect on Performance. The results of research revealed that coefficient value of 0.427 and significance level of $0.001<0.05$.

6. Work Motivation has a significant effect on Performance. The results of research revealed that coefficient value of -0.227 and significance level of $0.046<0.05$.

7. Organizational Justice has a significant effect on Performance. The results of research revealed that coefficient value of 0.259 and significance level of $0.043<0.05$.

8. Organizational Citizenship Behavior (OCB) can increase the effect of Organizational Climate on Performance. This research results indicate the total variable effect of Organizational Climate on Performance through OCB of $0.559>0.427$. This shows that OCB variable can mediate the variable of Organizational Climate on Performance Variables.

9. Organizational Citizenship Behavior (OCB) can increase the effect of Work Motivation on Performance. This research results indicate the total effect of Work Motivation variables on Performance through OCB of $-0.198>-0.227$. This shows that OCB variable can mediate the effect of Work Motivation variables on Performance Variables.

10. Organizational Citizenship Behavior (OCB) can increase the effect of Organizational Justice on Performance. This research results indicate the effect of total variables of Organizational Justice on Performance Variables through OCB Variables of $0.347>0.259$. This shows that OCB variable can mediate the effect of variable Organizational Justice on Performance Variables.

Based on the conclusions, should further improve a good organizational climate by reducing disagreements or opinion differences among fellow employees with superiors to create a comfortable working atmosphere. The job descriptions should be defined and structured clearly. Employees should be provided opportunities in terms of proposals democratically and doing good work consistent with their duties and responsibilities.

Motivation should be increased by right work placement. The assigned position should be consistent with educational background. Leaders together with other employees provide mutual support for employee achievements and provide training to employees to improve self-development.

Company should increase Organizations justice through comparable wages with the work and on time. Company should consistent to implement company regulations, with polite and equal treatment. Improve Organizational Citizenship Behavior (OCB) by helping each other without expecting rewards, replacing the absence co-workers, willing to work overtime without being given a salary and have sharing among employees in handling problems. Good organizational climate, high work motivation and Organizational Justice and supported by OCB, the employees should be able to complete the work above standard and fulfil the company target.

\section{REFERENCES}

A A Ngurah Bagus Danendra dan Ni Wayan Mujiati. 2016. Pengaruh Motivasi, Kompensasi Dan Komitmen Organisasional Terhadap Organizational Citizenship Behavior (OCB). E-Jurnal Manajemen Unud, Vol. 5, No. 10, 2016: 6229-6259 ISSN : 2302-8912.

A.M. Sardiman, 2007, Interaksi dan Motivasi Belajar Mengajar: Bandung, Rajawali Pers

Abuiyada, Hana S and Shih, Yung Chou. 2012. A Two-Factor Model of Organizational Citizenship Behaviour in Organizations. European Journal of Business and Management, 4(3): 134-144.

Agyemang, Badu Collins. 2013. Perceived Organizational Climate and Organizational Tenure on Organizational Citizenship Behaviour: Empirical Study among Ghanaian Banks. European Journal of Business and Management, 5(26): 132-142.

Ahmad, Sowana Wadud., and Tanzin, Khan. 2016. Does Motivation Lead to Organizational Citizenship Behavior A Theoritical Review.Global Journal of Management and Business Research, 16 (7): 43-49.

Andriani,Gita., M, Asad Djalali., dan Diah, Sofiah. 2012. Organizational Citizenship Behavior dan Kepuasan Kerja Pada Karyawan. Fakultas Psikologi Universitas 17 Agustus 1945 Surabaya.Jurnal Penelitian Psikologi, 03 (1): 341-345.

Anwar Prabu Mangkunegara, 2001. Manajemen Sumber Daya Perusahaan, PT. Remaja Rosdakarya, Bandung.

Anwarm Prabu Mangkunegara, 2000, Manajemen Sumber Daya Manusia Perusahaan, Cetakan Ke-2, PT. Remaja Rosda Karya, Bandung

Ariani, Dorothea Wahyu. 2012. Comparing Motives of Organizational Citizenship Behavior between Academic Staffs' Universities and Teller Staffs' Banks in Indonesia. International Journal of Business and Management, 7(1): 161-168. 
Arikunto, Suharsimi. 1998. Prosuder Penelitian Suatu Pendekatan Praktek. Jakarta: PT. Rineka Cipta.

Awang, Roslan., Wan, Mohd Rashid., and Wan, Ahmad. 2015. The Impact of Organizational Justice on Organizational Citizenship Behavior inMalaysian Higher Education. Mediterranean Journal of Social Sciences, 6(5): 674-678.

Baron, R.M. \& Kenny, D.A. 1986. The Moderator-Mediator Variable Distinction in Social Psychological Research: Conceptual, Strategic, and Statistical Considerations. Journal of personality and Social Psychology. 51 (6), 1173-1182

B. Uno, Hamzah. 2008. Teori Motivasi dan Pengukurannya, Jakarta : Bumi Aksara.

Brahmana, S.S. dan Sofyandi, H. 2007. Transformational Leadership dan Organization Citizenship Behavior di Utama. Laporan Penelitian. Tidak diterbitkan.

Cahayu, Putu Astri Suyesmi., dan Adnyani, I gusti Ayu Dewi. 2015. Pengaruh Keadilan Organisasi Terhadap Kepuasan Kerja dan Organizational Citizenship Behavior Pada Karyawan Toko Nyoman.E-Jurnal Manajemen Unud, 4(11): 3738 - 3765.

Colquitt, Lepine, Wesson. (2009). Organizational Behavior. McGrow Hill International Edition.

Danis, et al. 2014. Pengaruh Motivasi Kerja, Loyalitas Kerja Terhadap Organizational Citizenship Behavior (Ocb) Dan Kinerja Karyawan Pada Kantor Balai Pengelolaan Daerah Aliran Sugai Sampean Di Kabupaten Bondowoso. Jurusan Manajemen, Fakultas Ekonomi, Universitas Jember (UNEJ).

Davis, Keith,dan Newstorm. 1996. Perilaku Dalam Organisasi. Edisi Tujuh. : Erlangga.

Dewi Purwanti Dan Mafizatun Nurhayati. 2016. Pengaruh Iklim Organisasi Dan Tipe Kepribadian Terhadap Stres Kerja Dan Perilaku Kewargaan (Studi Pada Karyawan Klinik Laboratorium Prodia Cabang Menteng, Jakarta). Jurnal Manajemen/Volume Xx, No. 02, Juni 2016: 293-309.

Djati, S. P. \& Wahyu A. R. 2011. Penerapan organizational citizenship behavior dalam manajemen sumber daya manusia pada perguruan tinggi. Jurnal Mitra Ekonomi dan Manajemen Bisnis. 2 (2): 259-272.

Ek, Kiruja., and Elegwa, Mukuru. 2013. Effect of Motivation on Employee Performance In Public Middle Level Technical Training Institutions In Kenya. International Journal of Advances in Management and Economics, 2(4):73-82.

Fatimah O, A. M. Amiraa., and Halim, F. W. 2011. The Relationships between Organizational Justice, Organizational Citizenship Behavior and Job Satisfaction. Pertanika J. Soc. Sci. \& Hum,19 (5): 115-121.

Ghozali, Imam. 2006. Aplikasi Analisis Multivariate Dengan Program SPSS. Cetakan Keempat. Semarang: Badan Penerbit Universitas Diponegoro.

Goudarzvandchegini, Mehrdad., Shahram, Gilaninia., and Rahim Abdesonboli. 2011. Organizational Justice and Organizational Citizenship Behavior Case Study: Rasht Public Hospitals. International Journal of Business Administration, 2(4): 42-49.

Guilford, J. P. (1956). Fundamental Statistics in Psychology and Education. New York: Mc Graw-Hill Book Co. Inc.

Harper, Pamela J. 2015. Exploring forms of organizational citizenship behaviors (OCB): antecedents and outcome. Journal of Management and Marketing Research, 18(1): 1-16.

Harris Kristanto. 2015. Keadilan Organisasional, Komitmen Organisasional, Dan Kinerja Karyawan. JMK, VOL. 17, NO. 1, MARET 2015, 86-98 DOI: 10.9744/jmk.17.1.86-98 ISSN 1411-1438 print / ISSN 23388234 online.

Hasibuan, Malayu S.P, 2006, Manajemen Dasar, Pengertian, dan Masalah,Edisi Revisi, Bumi Aksara:Jakarta.

I Made Dika Mahendra dan Ida Bagus Ketut Surya. 2017. Pengaruh Iklim Organisasi, Motivasi Kerja Dan Keadilan Organisasi Terhadap Organizational Citizenship Behavior (OCB). E-Jurnal Manajemen Unud, Vol. 6, No. 9, 2017: 4569-4688

Ibrahim, M. A., \& Aslinda. (2014). The Effect of Motivation on Organizational Citizenship Behavior (OCB) at Telkom Indonesia in Makasar. Internasional Journal of Administrative Science \& ORganization , H. 114120.

Ibrahim, Mohamed E. dan Ann O.Perez. 2014. Effects of organizational justice, employee satisfaction, and gender on employees' commitment: evidence from the uae. International Journal of Business and Management. Vol. 9 No. 2. pp. 45-59.

Ince, Mehmet., and Hasan, Gul. 2011. The Effect of Employees Perceptions of Organizational Justice on Organizational Citizenship Behaviour :An Application in Turkist Public Institution. International Journal of Business and Management, 6 (6): 134-149.

Iqbal, H. K., Aziz, U., and Tasawar, A. 2012. Impact of Organizational Justice on Organizational Citizenship Behavior: An Empirical Evidence From Pakistan. World Applied Sciences Journal,19 (9): 1348-1354.

Isnawati, Cut., Said Musnadi, dan Nurdasila Darsono. 2012. Pengaruh moral, komitmen dan motivasi terhadap service quality pada pekerja sosial masyarakat (PSM) di Banda Aceh dengan organizational citizenship behavior $(O C B)$ sebagai variable intervening : studi kasus pada pekerja sosial masyarakat (PSM) di Banda Aceh. Jurnal Ilmu Manajemen. 1 (1) : 114-130. 
James L. Gibson, et.al., 2012. Organization : behaviour, Structure, Processes.14 ${ }^{\text {th }}$ Edition. New York: McGrawHill Companies, Inc.

Kumar, K., et al. 2009. Linking the Big Five Personality Domains to Organizational Citizenship Behavior. International Journal of Psychological Studies, 1(2):73-81.

Lubis, M. Saleh. (2015) "Pengaruh Iklim Organisasi dan Komitmen Organisasi terhadap Pembentukan Organizational Citizen Behavior (OCB) Karyawan dalam Rangka Peningkatan Kinerja”. e-Jurnal Apresiasi Ekonomi. 3 (2): 75-84, ISSN: 2337-3997.

Lunenburg, C. Fred and Allan C. Ornstein, 1991. Educational Administration Concepts and Practice. BelmontCalifornia: Wadsworth Publishing Company.

Luthans, Fred. 2002. Organizational Behavior: 7th Edition. New York: McGrawHill Inc.

Marcahyono. 2012. Pengaruh Kualitas Pelayanan Internaldan Motivasi KerjaTerhadap Kinerja Karyawan Menggunakan Path Analysis (Studi Kasus Pada PT. PG. Rajawali 1 Unit PG. Krebet Baru Bululawang Malang). Tesis.Universitas Brawijaya Malang.

Mathis, R.L. \& J.H. Jackson. 2006. Human Resource Management: Manajemen Sumber Daya Manusia. Terjemahan Dian Angelia. Jakarta: Salemba Empat.

Mathis, R.L. \& J.H. Jackson. 2006. Human Resource Management: Manajemen Sumber Daya Manusia. Terjemahan Dian Angelia. Jakarta: Salemba Empat.

McFarlin, D.B. and Sweeney, P.D. (1992) Distributive and Procedural Justice as Predictors of Satisfaction with Personal and Organizational Outcomes. Academy of Management Journal

Meylandani, Dharing. 2013. Hubungan Antara Iklim Organisasi Dan Organizational Citizens Behavioral (OCB) Pada Perawat RSUD Kanjuruhan Kepanjen Kabupaten Malang.Jurnal Psikologi Universitas Negeri Malang, 1(1): 1-13.

Moorman, Christine, Rohit Deshpande, dan Gerald Zaltman. 1993. "Factors Affecting Trust in Market Research Relationships". Journal of Marketing. Vol 57. pp 81-101.

Moradi, Mohammadreza. 2015. Modeling the Relationship between Work Motivation and Employees' Organizational Citizenship Behaviors of Youth and Sport Offices in Chaharmahal and Bakhtiari Province. European Journal of Physical Education and Sport, 7(1): 59-67.

Nandan, Tamizarasu., and Abdul, Mutalib Mohamed Azim. 2015. Organizational Justice and Organizational Citizenship Behavior: Mediating Role of Psychological Capital. American International Journal of Social Science, 4(6):148-156.

Nasurdin, A. M., \& Khuan, S. L. (2007). Organizational justice as an antecedent of job performance. Gadjah Mada International Journal of Business, 9(3), 335-353.

Ni Kadek Setya Prameswari dan I Gusti Made Suwandana. 2017. Pengaruh Keadilan Organisasional, Komitmen Organisasional, Dan Kepuasan Kerja Terhadap Organizational Citizenship Behavior. E-Jurnal Manajemen Unud, Vol. 6, No. 3, 2017: 1368-1397 ISSN : 2302-8912.

Ni Nyoman Trisna Suwandewi dan Desak Ketut Sintaasih. 2016. Keadilan Organisasional Dan Komitmen Organisasional: Efeknya Pada Organizational Citizenship Behavior. E-Jurnal Manajemen Unud, Vol. 5, No.7, 2016: 4453-4485.

Nwibere, B. M. 2014. Organisational justice as a determinant of organisational citizenship behaviour in the nigerain work environment: a study of selected universities in the niger delta region. International Journal Of Business And Management, 9(4): 191-205.

Oge, G Monanu., Okoli, Ifeanyi Emmanuel., Ezeliora, Martin Mmaduabuchi., and Okeke, Patrick Anene. 2014. Organisational Justice and Organisational Citizenship Behaviours among Academic Staff of Private Universities in

Oren, Lior Aharon Tziner., Yulia Nahshon., and Gil Sharoni. 2013. Relation Between OCBS, Organizational Justice, Work Motivation And Self Efficacy. Journal ofThe Protection of Consumer Rights in the Field of Economic Services, of General Interest, 15(34): 505-516.

Organ, D. W. 1988. Organizational citizenship behavior: The good soldier syndrome. Lexington, MA: Lexington Books.

Panggalih, Bening., dan Ratni Zulaicha. 2012. Pengaruh Kepuasan Kerja Terhadap Organizational Citizenship Behavior dengan Motivasi Kerja Sebagai Variabel Intervening Pada Karyawan PT. Telkom Tegal. Performance, 16(2): 1-15.

Podsakoff, Philip M, Scott B. MacKenzie, et all. 2000. Organizational CitizenshipBehavior: A Critical Review of the Theoritical and Empirical Literatureand Suggestions for Future Research. Journal of Management. Vol. 26,No. 3, 513-563.

Prihatsanti, Unika., dan Dewi Kartika Sari.2010. Hubungan Antara Iklim Organisasi Dan Organizational Citizenship Behavior (OCB) Pada Guru SD Negeri Di Kecamatan Mojolaban Sukoharjo. Jurnal Psikologi Undip, 7(1):11-16.

Purwanti, Dewi., dan Nurhayati Mafizatun. 2016. Pengaruh Iklim Organisasi Dan Tipe Kepribadian Terhadap 
Stres Kerja Dan Perilaku Kewargaan (Studi pada Karyawan Klinik Laboratorium Prodia Cabang Menteng, Jakarta). Jurnal Manajemen, 20(2): 293-309.

Putu Astri Suyesmi Cahayu Dan I Gusti Ayu Dewi Adnyani. 2015. Pengaruh Keadilan Organisasi Terhadap Kepuasan Kerja Dan Organizational Citizenship Behavior Pada Karyawan Toko Nyoman. E-Jurnal Manajemen Unud, Vol . 4, No. 11, 2015: 3738 - 3765 ISSN : 2302-8912.

Ratnawati dan Khairul Amri. 2013. Pengaruh Keadilan Organisasional, Kepercayaan Pada Atasan Terhadap Perilaku Kewargaan Organisasi (Organizational Citizenship Behavior). Jurnal Ekonomi Manajemen Dan Bisnis, 1(1) : 56-73.

Riduwan dan Sunarto.2007. Pengantar Statistik Untuk Penelitian Pendidikan, Sosial, Ekonomi dan Bisnis. Bandung : Alfabeta.

Ridwan Isya Luthfi, Heru Susilo, Muhammad, Faisal Riza. 2014. Pengaruh Motivasi Terhadap Kinerja Karyawan (Studi Pada PT Elsiscom Prima Karya, Kantor Perwakilan Surabaya). Jurnal Administrasi Bisnis

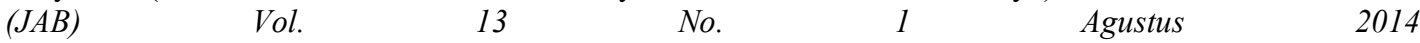
Imran Ukkas dan Dirham Latif. 2017. Pengaruh Iklim Organisasi Dan Komitmen Organisasi Terhadap Organizational Citizenship Behavior (OCB). Jurnal Equilibrium, Vol .06 No . 01 Februari 2017.

Ridwan Tantowi dan Hesti Widi Astuti. 2016. Pengaruh Iklim Organisasi Terhadap Kinerja Karyawan Pada Pt. Bank Danamon Simpan Pinjam Unit Metro. Jurnal Bisnis Darmajaya, Vol. 02 No. 02, Juli 2016.

Rohyani, Indah. 2014. Pengaruh Keadilan Organisasi Terhadap Kepuasan Kerja Dengan Personality(Kepribadian) Sebagai Variabel Pemoderasi(Studi Empiris Pada Dosen Perguruan Tinggi Swasta Di Kabupaten Kebumen). Jurnal Fokus Bisnis, 14(2): 62-80.

Sanhaji, Akhmad., Budi, Eko Soetjipto., dan Suharto. 2016. Pengaruh Keadilan Organisasi Dan Budaya Organisasi Terhadap Perilaku Kewargaan Organisasi Melalui Komitmen Organisasi Dan Kepuasan Kerja. Jurnal Pendidikan Teori, Penelitian, dan Pengembangan, 1(5): 917-926.

Sani, Achmad. 2013. Role of Procedural Justice, Organizational Commitment and Job Satisfaction on Job Performance: The Mediating Effect of Organizational Citizenship Behavior. International Journal of Business and Management, 8(15):57-67.

Shahin, Arash., Naftchali, Shabani Javad., dan Pool, Khazaei Javad. 2014. Developing a model for the influence of perceived organizational climate on organizational citizenship behaviour and organizational performance based on balanced score card.International Journal of Productivity and Performance Management, 63( 3): 290-307.

Siagian, Sondang P, 2006, Teori Dan Kepemimpinan, Penerbit Rineka Cipta, Jakarta

Soentoro, D. P. 2013. Pengaruh Motivasi Kerja, Kepemimpinan, Lingkungan Kerja Terhadap Organizational Citizenship Behavior Dan Kepuasan Kerja Di PT Sucofindo Surabaya.

Stringer, Robert. 2002. Leadership and Organizational Climate. Prentice Hall. New Jersey.

Sudarmanto. 2009. Kinerja dan Pengembangan Kompetensi SDM (Teori, Dimensi Pengukuran dan Implementasi dalam Organisasi). Yogyakarta : Pustaka Pelajar

Sugiyono. 2002. Metode Penelitian Administrasi. Bandung : CV Alfabeta.

Sugiyono. 2004. Metode Penelitian. Bandung: Alfabeta.

Sugiyono. 2008. Metode Penelitian Kuantitatif Kualitatif dan R\&D. Bandung : ALFABETA

Suifan, Taghrid S. 2016. The Impact of Organizational Climate and Psychological Capital on Organizational Citizenship Behavior.International Journal of Business and Management, 11(1): 224-230.

Suliman, A., \& Kathairi, M. A. (2013). Organizational justice, commitment, and performance in developing countries. Employee Relations, 35(1), 98-115.

Supranto, J. 2001. Pengukuran Tingkat Kepuasan Pelanggan untuk MenaikkanmPangsa Pasar. Jakarta: Rineka Cipta.

Suwandewi, T.N \& Sintaasih, K.D. (2016). Keadilan Organisasional dan Komitmen Organisasional: Efeknya Terhadap Organizational Citizenship Behavior. E-Jurnal Manajemen Unud, 5 (7).

Suwardi, Joko Utomo. 2011. Pengaruh Motivasi Kerja, Kepuasan Kerja, Dan Komitmen Organisasional Terhadap Kinerja Pegawai (Studi Pada Pegawai Setda Kabupaten Pati). Analisis Manajemen Vol. 5 No. 1 Juli 2011. ISSN : 14411- 1799

Tahseen, Nosheena., and Muhammad Saeed Akhtar. 2016. Impact of Organizational Justice on Citizenship Behavior: Mediating Role of Faculty Trust. Pakistan Journal of Commerce and Social Sciences, 10(1): 104121.

Törnblom, K. Y. (1992). The social psychology of distributive justice. In Scherer, K. R. (ed.), Justice: Interdisciplinary Perspectives, Cambridge University Press, pp. 177-236

Ukkas, I., dan Latif, D. 2017. Pengaruh Iklim Organisasi Dan Komitmen Organisasi Terhadap Organizational Citizenship Behavior (OCB). Jurnal Equilibrium. Vol. 06, No. 01. 
Wahjosumidjo, 2001. Kepemimpinan Kepala Sekolah Tinjauan Teoritik dan Permasalahannya. PT. Raja Grafindo Persada, Jakarta.

Waspodo, Agung AWS., dan Minadaniati, Lussy 2012.Pengaruh Kepuasan Kerja Dan Iklim Organisasi Terhadap Organizational Citizenship Behavior (OCB) Karyawan Pada PT. Trubus Swadaya Depok.Jurnal

Wirawan, Nata. 2002. Cara Mudah Memahami Statistik 2 Statistik Inferensial untuk Ekonomi dan Bisnis. Edisi Kedua. Denpasar : Keraras Emas.

Yuliati. 2016. motivasi kerja, kepuasan kerja, komitmen organisasi, dan Organizational Citizenship Behaviour (OCB) (Studi Empiris Pada SMK Swasta Kecamatan Gayamsari Semarang). Jurnal Ilmiah UNTAG Semarang, 5(1): 23-37.

Yuwono, Susatyo, Kartika PS, dan Verry Ferdiana. 2014. Hubungan antara MotivasiKerja dan Kepuasan Kerja dengan Organizational Citizenship Behavior(OCB). Seminar nasional dan call for paper hal. 444-451.

Yuwono,dkk. (2014). Hubungan antara motivasi kerja dan kepuasan kerja dengan organizational citizenship behavior (OCB). Sancall: Research Methods and Organizational Studies, 444-451

Zabielske, Jurgita Lazauskaite., Ieva, Urbanaviciute., dan Dalia Bagdziuniene. 2015. The role of prosocial and intrinsic motivation in employees citizenship behavior. Baltic Journal of Management, 10(3): 345-365.

Journal of economic and financial science

ZAR; South africa rand 